\title{
Creating Multimodal Texts Online to Improve Young Adults' English Skills at Two State Institutions ${ }^{1}$
}

\section{Creación de textos multimodales en línea para mejorar las habilidades en inglés con jóvenes en dos instituciones públicas}

\author{
Diana Pahola Galvis Pinzón ${ }^{2}$ \\ Colegio Trinidad Camacho Pinzón, Cite, Santander \\ Linda Lucía Callejas Afanador ${ }^{3}$ \\ Universidad Industrial de Santander, Socorro, Santander
}

Received: March 4, 2016

Accepted: July 12, 2016

How to cite this article (APA, $\mathbf{6}^{\text {th }}$ ed.): Galvis, D., Callejas, L. (2016). Creating Multimodal Texts Online to Improve Young Adults' English Skills at Two State Institutions. Enletawa Journal, 9 (2), 35-54

\begin{abstract}
This paper aims to describe the creation of multimodal texts as a pedagogical strategy implemented through the use of ICT tools in two state institutions in the Colombian province of Santander. After analyzing teaching practices, it was observed that written texts were usually approached in a linear manner without taking into consideration other text modes, which may lead students to lose interest in literacy practices. Accordingly, an action research was conducted following a

1 This research report is the result of the ICT and CALL Seminar of the Master's in Language Teaching at Universidad Pedagógica y Tecnológica in Tunja.

2 Holds a BA in Modern Languages and a specialization in Educational Management from UPTC University. She has experience as an English teacher in private and public institutions. She is currently working in a Public school in Cite, Santander

3 Holds a B.A in English Teaching from Universidad Industrial de Santander. Nowadays, she is working in a branch of a public University in Socorro, Santander. Her research interests are on second language learning, learning strategies and critical literacy.
\end{abstract}


qualitative paradigm based on a descriptive-interpretative methodology. The research results suggested learner improvement resulting from the use of ICT for educational purposes, learning English through the implementation of integrated skills, and working collaboratively. It was also concluded that when creating multimodal texts, it is important to bear in mind both: students' perceptions of the world and the role of the teacher as a facilitator of ICT tools for academic purposes in virtual learning environments.

Key words: blended learning, learning environments, multimodal texts, friendship, and love relations.

\section{Resumen}

Este trabajo pretende compartir la creación de textos multimodales como una estrategia pedagógica implementada a través del uso de herramientas TIC en dos instituciones públicas del departamento de Santander. Después de analizar las prácticas de enseñanza, se observó que los textos escritos se abordaban de forma lineal, sin tener en cuenta otros modos textuales, lo que podría llevar a los estudiantes a perder interés en las prácticas de literacidad. En consecuencia, se realizó una investigación-acción siguiendo un paradigma cualitativo basado en un método descriptivo-interpretativo. Como resultado, los estudiantes mejoraron aspectos como el implementar las TIC con fines educativos, perfeccionar el idioma por medio de aprendizaje combinado y trabajar colaborativamente. Se concluyó que al crear textos multimodales es importante tener en cuenta las percepciones de los estudiantes sobre el mundo y el papel del profesor como facilitador de herramientas TIC en ambientes virtuales de aprendizaje.

Palabras clave: aprendizaje combinado, ambientes de aprendizaje, textos multimodales, relaciones de amistad y amor. 


\section{Introduction}

The field of language acquisition is rapidly undergoing changes based upon how learners interact with all of the technological changes happening in our times, which means that integrating digital spaces into the foreign language classroom is necessary. In the Colombian context, educational policies also demand this kind of integration. However, as Ariew \& Ercetin (2004) point out, the use of computers affects the way we interact with texts because we are used to reading printed texts in a primarily linear way, but nowadays more reading is non-linear. Despite this fact, some schools are not allowed to use electronic devices, some teachers do not receive technological training, and students often lose interest and see reading and writing as non-enjoyable practices.

This article describes a small-scale project that involved foreign language students' using multimodal texts to create audiobooks, for which learners were assigned roles in the creation process taking into account their stren-gths and weaknesses, an approach which resulted in the improvement of their receptive and productive skills. A learner-centered approach was implemented by delegating tasks that met instructional needs as well as syllabus and website objectives. The website Little Bird Tales was chosen since it promotes digital storytelling, combines modes of texts, records other's tales, and uses visual and auditory technological tools. The use of this webpage allowed students to work collaboratively with other communities of foreign language learners, to improve English skills such as reading, writing, speaking and listening, and to learn how to use technology for academic purposes. By doing so, students were able to express their perceptions on topics related to experiences as writers in a virtual environment, especially writing as a reflection of real life based on different situations from the tales.

\section{Statement of the Problem}

In two public institutions, a high school and a university in Santander, two English teachers noticed that they both addressed literacy practices in the same manner, namely by using linear texts, and that this approach appeared to yield a low level of students' interest in reading and writing. Moreover, their course curricula had common achievement outcomes, such as the development of reading and writing practices to accomplish tasks based on administrative directives as well as international and national policies.

In the case of the high school, those achievement outcomes had to do with accomplishing National Policies like: NBP (National Bilingual Program), Colombia Very Well 2015-2025 and Standards of Language. In the case of the university, both collaborative practice and use of technological tools 
are the mainstays of the curriculum. This reflects the national policies which aim to foster language learning by using ICT (Information and Communication Technology) tools and applications; in fact, all education institutions are mandated to have access to technological devices which facilitate direct or simulated discourse (Colombia Very well, 2014).

However, in one of these two public institutions, classrooms were not provided with enough technological resources to integrate ICT into English; consequently, students were not familiar with multimodal texts presented in web pages, which represented an obstacle to fostering literacy skills in students. Common needs evident in both institutions included: the need to develop literacy tasks; a need to collaborate with other learning communities; and the need to improve language learning skills, expand the use of ICT, and assume critical positions related to what students read and write. After analyzing the common issues in both contexts, it was necessary to establish a strategy that would fulfill at least some of those needs as well as encourage both teachers to incorporate ICT into their classes.

\section{Literature Review}

\section{Literacy and Multimodality.}

Terms such as new literacies (Lankshear \& Knobel, 2003), multiliteracies (Cope \& Kalantzis, 2000) and multimodality (Kress
\& van Leeuwen, 2001) are based on how people make meaning with texts. Such terms have conceptualized the way new communication practices are impacting literacy and learning, as described by Jewitt (2008, p.242). Here, literacy has a key feature, multimodality, which was recognized in this study as a pedagogical strategy because it provided the tools for working with blended learning. For instance, the website Little Bird Tales combined tools such as uploading photos, drawing pictures, written text, and online audio voice recordings.

All those tools reflected the definition of multimodality as meanings conveyed, interpreted, and reconveyed via image, sound, writing, music, speech, etc (Kress \& Van Leeuwen, 2001). From a multimodal perspective theory, it is explained by Kress and van Leeuwen (2001) that images and actions are referred to as modes that organize sets of semiotic resources for meaning making of texts. In this sense, researchers considered the need to go beyond literacy practices as only written representations. That is why in this process of literacy, students learn "what counts as literacy" (Unsworth 2001, p. 337) in the classroom, how the construction of literacy is developed, and how it occurs through understanding texts They also learn to appreciate a wider range of texts as well as interacting with other readers.

Nowadays, the word literacies in new literacies signals a shift in thinking 
about the ways that people make meaning with language (Rowsell \& Walsh, 2011). Traditionally, literacy is seen as a product whereby learners analyzed text genres and vocabulary. That is why moving literacy beyond standard forms of written and spoken language is a difficult task (Vaarala \& Jalkenen, 2010).

Barton, Hamilton \& Ivanič (2000) define literacy practices as activities taking place around texts. In this research, literacy was perceived as an opportunity for students to interact with their knowledge of the world and connect the texts with topics such friendship and love relations. This social perspective "enables an analysis of how the social practices of literacy in schools realize social structures" (Jewitt, 2008, p. 241). This concept reflects the way in which literacy practices can be used to create connections and interpersonal relations and how learners' perceptions on those topics shape how they read, understand and write a text. Moreover, the way learners react to certain topics emerging in their written papers highlights the interaction between writer, reader and text.

\section{Blended learning.}

The term blended learning is defined from a point of view in which singularity is not as effective for educational purposes. Masie claims that "we are, as a species, blended learners" (as cited in Hoffmann \& Miner, 2002, p.4). It means that humans are able to learn using different ways to study a specific topic and thus we employ multiple methods to acquire knowledge. Therefore, Garrison \& Kanuka (2004), mention that the "integration of classroom faceto-face learning experiences with online learning experiences." (p.96), although not the same for all contexts and with varied effects on learners, appears consistent with our natural inclination to multimodal learning.

In digital spaces, blended learning often has different semantic modes that contain messages and information shared by different communities arranged around common educational goals. Garrison \& Kanuka (2004) affirm that in a blended learning scenario, much of the learning is via written communication because the interactions are often a synchronous. Individuals are part of communities of inquiry in which knowledge is negotiated with other individuals that belong to the same community, primarily in written form.

\section{Collaboration.}

For the purpose of this study, collaboration is considered "a process of shared creation: two or more individuals with complementary skills interacting to create a shared understanding that none had previously possessed or could have come to on their own" (Schrage, 1995, p.33). It implies a cooperative approach to knowledge acquisition whereby individuals help each other to achieve common goals. 
In this study, students were assigned different tasks according to their strengths or weaknesses regarding the 4 primary English skill areas: writing, reading, speaking and listening. The final product was an audiobook created not in isolation but in a working group. To that end, students assumed roles as writers, editors, speakers, listeners and designers. The purpose was both to help them to improve their abilities in weaker areas as well as reinforce and expand upon prior knowledge of language. The whole experience meant "participants working together on the same task" (Lai 2011, p. 7), the very goal of collaborative task-based language practices.

In virtual environments, collaboration can sometimes be confused with cooperation that is to work simultaneously to accomplish a task. Maintz (2009) explains that collaboration in virtual environments has to do with interactions in a synchronous way (chatting or having video conferences) or in an asynchronous way (e-mails, forums, blogs). However, and for the purposes of this study, attention was given to asynchronous formats because the means to communicate the tales was via Google Drive, e-mails, and the information participants uploaded in Little Bird Tales. In this sense, the cyberspace is also a way to provide students with opportunities to share with other academic communities.

One study that illustrates how collaboration is facilitated using written texts was conducted by Bear, Estreem, Fredrickson \& Shepherd (2014). One of the main purposes was to connect technology and literacy through digital spaces. They highlight the importance of considering writing not as an individual skill of self-expression but as a construction of a participatory culture in digital spaces. They concluded that negotiation through a written text online can be facilitated using Google Docs or a similar platform because it allows students to have a safe space to exchange knowledge and content.

Collaborative practices in the language class are useful to connect students with other learning communities and one of the advantages, as explained in Bear, et al. (2014), is that this interaction can be both promoted through Virtual Learning Environments (VLE) via the written word, whereby the texts students create constitute a form of communication.

\section{Methodology}

\section{Research Design.}

This study followed a qualitative paradigm. Informed by the work of Johnson \& Christensen (2004), it relied primarily on the collection of qualitative data which, in this case, consisted of written texts that students wrote as well as insights they provided through the questionnaire. The type of study was action research, which Tripp defines as a method used in education when teachers want "to improve their 
teaching and thus their students' learning" (2005, p.2). The main objective was to integrate technology to the daily classes by tackling deficiencies in the way written texts were addressed in an effort to restore a degree of student interest and motivation.

Tripp (2005) proposes an action research cycle formed by three phases: The first planning phase calls for analyzing the problematic situation. This step included observations of English classes in which researchers detected students' low interest in literacy practices and followed by planning of ways to improve. The second phase was the action phase, during which students created the audiobooks and data was collected from the questionnaires. The last phase was evaluation, in which a triangulation was made between excerpts from the tales and data provided in the questionnaires related to students' perceptions of love and friendship relationships, the use of technology, and their English skills.

\section{Setting and Participants.}

This study was carried out in two different institutions. The first was a branch of a public university located in Socorro, Santander. The 13 voluntary participants included 6 female students and 7 male students between 17 and 22 years old enrolled in engineering programs. They came from different academic backgrounds (rural, state, and private schools) and were receiving five hours of English instruction per week.
After exploring the webpage, students decided to assign different roles such as writers, editors, speakers and designers of the audiobooks.

The other participants were 30 eleventh graders whose ages ranged between 16 and 20 years, consisting of 22 girls and 8 boys from a public senior high school in the town of Barbosa. They came from Colombian socioeconomic strata one, two, and three. They were well-behaved students but they had more difficulties with scholastic material. They studied three hours of English weekly, and they made use of an information and technology branch of their school. These students had a basic level of English and studied in a context in which the English subject is one of the fundamental subjects in the curriculum. Students in the two institutions were chosen to participate in the project because of their manifested interest in improving their English skills.

\section{Data Collection Instruments.}

\section{Students' production.}

The tales written and posted by the students were used as a means to unveil relations between their lives and main topics of their texts. The audiobooks and the process of editing in Google Docs were also considered. The data provided by these sources helped to determine the main topics to explore in the questionnaires, to make connections between what and how students wrote and learn more about their perceptions. 


\section{Questionnaires.}

Participants were asked to answer an open questionnaire. It was divided into three different sections which included students' perceptions and opinions connected to the topics from the tales, use of technology tools, and learning the language through skills practice and collaborative work (See Appendix A). The first section included three subdivisions which were administered after teachers had identified emerging social topics in the tales. Those topics were chosen due to their social nature; researchers explored how student friendship and love relations were strengthened and the connection they made with the interpretation of tales.

The second section contained questions regarding the ways students learned about the website Little Bird Tales and the programs and tools used for task completion in cyberspace. The third section addressed questions related to foreign language learning which encompassed three further subdivisions: English skills, collaborative work with other institutions, and perceptions related to the whole experience.

\section{Pedagogical Implementation}

The integration of resources for teaching English in the language classroom was planned based on the tools available in Little Bird Tales. According to its creators, the website aims to foster love for reading, writing, and self-expression, and to make the foreign language learning process easier and funnier for students and teachers. To that end, the webpage promotes learning by sharing stories, opening accounts, using multimedia, recording sounds, uploading pictures, writing stories and creating drawings.

The website was integrated to the syllabi of the two courses through three stages. The first stage was in-depth information about project, explaining to learners its purpose, dealing with consent forms, understanding resources needed and working with templates for Tales. In this stage, teachers taught students how to use the website, assigned work groups, and facilitated the creation of Gmail accounts. The second stage, the more hands-on stage, included signing into the website, editing texts, and creating visual and audio recordings. Activities such as peer-checking, feedback on recordings, sharing tales, and commenting on the experiences were implemented during the third stage.

Students were assigned to work on tasks according to their strengths and weakness in English skills. The tasks were addressed taking into account the curricular direction that teachers in both institutions had to follow. Thus, two goals were set regarding the institutional syllabi from the public school: "to produce written texts with different intentions considering[the] possible reader" and "to understand different texts and assume a critical 
position according to them." (Colegio Trinidad Camacho Pinzón, 2016, p.68). Some additional objectives were taken from the public university curricula based on the book Cutting Edge Elementary, such as "students can write a series of simple phrases and sentences linked with simple connectors like and, but and because" and "student can identify specific information in simpler written material he/she encounters such as stories describing events in past simple." (Greene, Cunningham \& Moor, 2013, p.3).

\section{Results}

Data was collected during three weeks in which students worked on the creation of audiobooks. The triangulation strategy used to analyze "data gathered by multiple methods (e.g., observation and interviewing)" (Elliot \& Timulak, 2005, p.151) helped to do a cross-validation between the information from the questionnaire answered by the 43 students and the written texts produced by them. The strategy was used to assure reliability during the process. The analysis was based on a descriptive and interpretative framework that allowed the consideration of the importance of using virtual environments to foster literacy practices in the English class.

To carry out the analysis, a grid was made to classify the five tales written by the students; it was essential to extract segments that embraced a social connotation in terms of how those tales reflected students' daily experiences, based on perceptions about friendship and love relationships. Upon analyzing the data, two patterns emerged. The first one called My experience as a language learner in virtual environments was divided in two subcategories: Writing as a reflection of life and Approaching ICT in the English class. The second category was named Using ICT to improve my English skills.

\section{My experience as a language learner in virtual environments.}

When students worked in Google Drive and Little Bird Tales, they were able to communicate their views of life through writing and at the same time, they learnt how to use technological tools as means to express their perceptions.

\section{Writing as a reflection of life.}

This had to do with how students represented their real lives when they were involved in literacy practices. The themes found in the tales were related to friendship and love relationships. When learners were asked how they reacted when facing problems in a friendship or love relation, their answers had positive and negative connotations. Students who answered negatively claimed, for instance: 
"I do not do anything unless the person is important for me" (Q, S. 13) ${ }^{4}$

["no hago nada al respecto al menos que la persona sea importante"]

or even they said,

"I avoid problematic situations because facing problems is difficult for me" (Q, S. 4). ["evado la situación ya que me es difícil enfrentar los problemas"]

In the tales, the ways in which students assumed negative attitudes was evident, especially when they were in trouble. In this extract, they wrote:

"He was walking and every step was without reasons, alone [he] wanted [to] escape of this unkind reality." (Tale 1 )

"Then, he wanted to be alone, in a place very very far from his house" (Tale 3)

Students that answered positively mentioned:

"I searched for solutions to the problems (talking in a respectful and tolerant way)" (Q, S. 16)

["busco soluciones a los problemas (hablando de manera respetuosa y tolerante)"]

Additionally, University students' responses were:

"I express what I dislike about the problem" (Q, S. 35) [Expreso lo que me

4 Codes used: $S=$ Student, for perceptions written in the questionnaire $=\mathrm{Q}$ and (Tale 1), (Tale 2), (Tale 3), (Tale 4) and (Tale 5) for the tales incomoda durante el problema] And "I assess the alternatives and ask for advice" (Q, S. 38) [Evaluo alternativas y pido consejo] The tale that supported this perception was:

"She was married. It broke his heart and he decided to give up. He went to look for [an] other rat, a rat that was arranged to love him." [sic.] (Tale 2).

They also claimed that when they had problems they faced it, e.g

"I express what bothers me of the situation" (Q, S. 36).

["Expreso lo que me incomoda durante el problema".]

It is supported by the texts as follows:

"It left forever, wished the better thing him and decided to forget what had happened between them" [sic.] (Tale 3)

"and his confirmed to him that was time to should forget her and he follow his live" [sic.] (Tale 5)

Bearing in mind the social perspective in which literacy is addressed in this article, one can say that according to students' perceptions, tales were written based on how learners may react when facing issues about friendship and love relations or finding solutions to tackle real life problems. That is why this study is viewed through the lens of social perspectives in literacy because it 
is understood as a social practice rather than an individual one.

\section{Approaching ICT in the English class.}

This subcategory reflects students' answers related to how they dealt with the resources available in Little Bird Tales and the other software used to create the audiobooks. Students were instructed about ICT use through a blended learning methodology that allowed the combination of face-toface instruction and online experiences (Garrison \& Kanuka, 2004). Face-toface instruction in classrooms was required to explain how to use the webpages using internet or PowerPoint presentations; the use of online tasks allowed students to use audio and visual modes to create the tales was also useful to get new knowledge of ICT tools. Students reported:

"I learned a new way to create animated texts with pictures with my teacher's help." (Q, S. 36)

[Aprendí una manera de crear textos animados con imágenes y con la ayuda de mi profesor]

"Our teacher showed us a video to learn how to use the website and I also searched by my own" (Q,S. 33)

[Nuestra profesora nos mostró un video de cómo usar la página y también yo misma busqué]

Other strategies used to learn about the websites were the autonomous exploration of the cyberspaces and watching YouTube tutorials, for ins-tance:

"Surfing the web and exploring" (Q, S.7)

[Navegando en internet y explorando]

During the process, it was found that even when students were digital natives or had grown up surrounded by "computers, videogames, digital music players, video cams, cell phones, and all the other toys and tools of the digital age" (Prensky, 2001, p.1). There were, however, some basic virtual tasks that they had not encountered before using the web pages in the language class. After working with the multimodal tasks, they acquired abilities in: uploading texts, imagery and audios in Little Bird Tales, editing texts on Google Drive, using a sound assistant and voice recognition with a microphone, using online dictionaries, and using their e-mail accounts for academic purposes.

In this paper, connecting the two learning environments had a common goal: to explore a website using inperson support from class as well as computer assisted learning. Students also employed different technological tools such as Google Drive, Google image search, Gmail, and Little Bird Tales tools, and those activities represented an alternative for learning the language. It allowed that the "environment becomes more learningcentered, with emphasis on active learning through collaboration and social 
construction of understanding" (Rovai \& Jordan, 2004, p.1).

\section{Using ICT to improve my English skills.}

This section describes how students' English learning was enhanced after integrating ICT into the classes. Students were asked about their improvement related to reading, writing, speaking, and listening, as they had previously worked on their weaknesses from those skills. During the process, students were also asked about collaboration to improve those skills and affective factors related to the English task assigned. One of the advantages of creating the audiobooks was the fact that it allowed the integration of the four skills without splitting them one by one. During the whole activity, students were simultaneously involved in comprehensive and productive practices using written, visual and auditory modes.

According to the students' answers, their writing, reading, and listening skills were strengthened by the writing process itself. When students started to write the tales, they became more conscious about the structure of sentences and paragraphs.

"It helped me to use structures, to write better, to know how to rewrite new words and to form coherent paragraphs." (Q, S. 13) ["Ayudó a estructurar, redactar mejor, saber re-escribir palabras nuevas y formación de párrafos coherentes"]
In most of the cases, students write their texts, teachers revise them and a score is assigned; students write a paper and then they forget the content because they do not return to those texts. In this case, once the tales were ready, students found a purpose to their written papers by using them to create the audiobooks. It helped learners to reinforce the structures and vocabulary they used during the writing assignment. For example, typing the texts in Google Drive helped them to understand more the content of tales they wrote. They claimed:

\footnotetext{
"Reading and understanding the text by copying it in the website" (Q, S. 25)

["leer el texto y comprenderlo al reescribirlo en la página"]
}

Students also reported that they reinforced their writing and reading skills when editing the texts. They had to understand the tales, carefully revise grammar structures, and rewrite some fragments when necessary. They also wrote comments and questions to their partners which established real English communication with the authors of the tales in the process of correction. Looking for imagery on the net to visually support the written texts also required reading the texts to fit the best pictures to the audiobooks. It also reinforced the reading skill not only of written words but of visual texts in the net. 
"Correcting mistakes and using connectors increased vocabulary and past tense knowledge" (Q, S. 42)

[Corrigiendo errores y usando conectores, aumentó el vocabulario y conocimiento de verbos en pasado"]

"It helped to expand vocabulary by searching for key words to comprehend better by using imagery" (Q, S. 36)

[Ayudó a ampliar el vocabulario al buscar palabras claves para entender por medio de imagen la comprensión de lectura"]

The integration of the reading and speaking skills in the recording of audios in the webpage was evident. The students' answers about reading a text aloud several times showed that it is an activity that favors pronunciation, fluency and reading comprehension. Moreover, it is a way to make students more conscious of their use of language as they correct their own mistakes after recording an audio. One student in charge of the speaking task (they were assigned different roles according to their strengths and weaknesses) answered:

"I learned to correct the pronunciation of verbs by myself, I used a better intonation when recording the audios and improved fluency when reading." (Q, S. 41)

[Aprendí a corregirme la pronunciación de verbos, a usar mejor entonación al grabar y mejoré la fluidez al leer]

Listening skills were supported by the work made during the writing process and the several readings students had to do to correct and edit the texts. Students perceived an observable improvement during this process as they had to write, edit, and read the texts, becoming more familiar with the vocabulary used in the audiobooks and understanding the texts aurally. They claimed:

"I learned how to listen and to translate using my mind" (Q, S.37)

[Aprendí a escuchar e ir traduciendo en mi mente]

"I understood more by listening to my partners and other's tales." $(Q, S .20)$

[Comprendía más escuchar al compañero y al escuchar a otros cuentos]

In collaboration, students pursued a common goal, worked in the same task, and negotiated knowledge. The common goal was to create the audiobooks by doing tasks like writing, editing, illustrating, and recording. Among themselves, students negotiated their editing skills with the purpose of being corrected by each other and supported by partners, as they indicated in the questionnaires. This collaboration with another institution enabled them to belong to a community of learning aiming at the same objective: to create audiobooks using ICT. Most of the high school students had a positive experience because they felt that this interaction with university students could help them to be involved in the higher education life. Some positive comments they wrote were: 
"It was very positive due to the fact they helped us to correct and we learned a lot" $(Q, S .17)$

[Sí fue positivo ya que ellos nos pudieron corregir y así aprendimos más]

"I liked the fact that they could see what I wrote and checked my mistakes so I realized about what was wrong." (Q, S. 12).

[Me gustó que ellos pudieron ver lo que yo escribí y corregir los errores y asi darme cuenta lo que tenía mal]

In regards to the connection between students' perceptions towards working with other people from different institutions, collaboration was seen as a creative process where students worked in a complementary manner. Here, each learner's role was based on the way knowledge was constructed and transformed for him/her; due to that fact, they understood that each person is a particular individual, but if they work collaboratively, the whole group's experience is enhanced through valuing others' ideas and perceptions.

The benefit of student collaboration is illustrated by such comments as:

"I helped myself with a classmate support and I learned how to use the dictionary" $(Q$, S. 31)

[Me colaboré con la ayuda de un compañero $y$ aprendi a usar el diccionario]

Also, students showed their positive reaction by stating that:

"I like the way in which students from Barbosa express their ideas throughout their tales and not only the time was used to this purpose, but also I worked at home, it was entertaining to see how people think about their problems in different situations by the tales"

[Me agradó la manera en que los chicos de Barbosa expresan sus ideas por medio de los cuentos y que se usa el tiempo tanto de la clase como en mi casa, era entretenido ver lo que otras personas reflexionaban sus problemas en diferentes situaciones a través de los cuentos] (Q, S. 28)

Those statements showed that collaboration "involves participants working together on the same task" (Lai 2011, p. 7) and not in an individual way. Dillenbourg, Baker, Blaye \& O'Malley (as cited in Lai 2011, p. 39) claim that collaboration implies negotiation in which none of the participants imposes his perspective; rather, they share knowledge and listen to the others.

Additionally, in their own institutions, they had negative and positive experiences. They wrote,

"Collaborative learning was noticed since we shared the activities and work tasks were distributed" (Q, S. 41)

[se notó aprendizaje colaborativo ya que se complementaron las actividades y se distribuyó el trabajo]

"it was positive because we used the class time, but some of us worked more than others" (Q, S. 4).

[fue positivo el uso tiempo de la clase, pero unos trabajan más que otros]

This indicates that students found it relevant to assume roles such as editing, recording their voice, and creating questions when they had to 
accomplish academic assignments with their partners. It further indicates how learning is nurtured by social practices rather over a solitary approach.

Not all feedback was positive. Some students described problems perhaps related to the lack of knowledge about how to use ICT, for instance:

"There was an issue with the e-mails," $(Q, S$. 12).

[Hubo un inconveniente con los correos]

The availability of time to meet outside the classroom and the different positions (for example leadership) they had in the groups also proved challenge for students during the tasks. They claimed:

"There was a problem to meet up, [and] some members in the groups scolded us a lot" $(Q$, S. 28)

[Había dificultad al reunirse, algunos miembros del grupo nos regañaban mucho]

That fact suggests that in such a setting, students needed to be monitored by the teacher even when the activities were meant to be worked on outside the language classroom. Nevertheless, this situation also showed how those initial activities are the starting points towards creating more autonomous students.

According to the given definition of collaboration in this study, interaction was not only present among individuals but also with the virtual environment itself, in which students developed the activities assigned by the teacher. As the participants in this study wrote their tales and created the audiobooks, interaction between the writer and the reader was established; they made comments and corrections in Google Docs, and it was then the teacher who brought up their ideas in the language classroom, in both the high school and the university. The interaction took place in a virtual space and the tales were means of facilitating communication among students and teachers.

During the process, some students expressed different emotional reactions to the use of ICT in the English classes, the work with other communities, and the writing of texts. When they were asked if they were motivated using ICT to create audiobooks, most of them found the activities productive, innovative, interesting and entertaining because they had never worked those kinds of projects in the English class. A student wrote:

"it is an interactive way of learning and growing" (Q,S. 34)

[Forma interactiva de aprender y fortalecer]

Other students did not find the webpage as motivating as their partners did, even when they had accomplished the assigned tasks. They found the web pages boring and/or difficult to use because the interfaces were written in English, and some of them perceived a lack of organization in the activities. 
I believed it is a well-designed program but it was very boring. $(Q, S .11)$

[Creo que es un programa bien diseñado pero muy aburrido]

"There was a great difficulty to understand the website because of the process [we had] to follow" (Q, S. 10)

[Hubo una gran dificultad para entender la página por el proceso que se tenía que seguir]

\section{Conclusions}

Literacy is considered in this study as part of a transformation of social realities, thus assigning topics regarding personal relations in terms of love and friendship was an opportunity to inquire into how learners connect topics of the tales with their lives. It is said that society is shaped by the relation to language and representations thereof; the delivery mode outlined in this study required both students and teachers to take into consideration the strengthening of social and human relations in both, students' experiences as writers in virtual environments, and how this experience reflected their life (perceptions, ideas and problems). The curriculum makes meaning of what is being learned and teaching is understood in a multimodal classroom environment.

This study also showed that one way to integrate different modalities is by utilizing ICT tools in the English classes or in assignments outside the English classroom. The use of technology was a way to introduce students to the target language and to the different visual, auditory, and linguistic modes in which that language was presented. The webpage in this study played an important role because it helped learners to interact with the tales by expanding the meaning of the topics with audio, words and pictures.

The combination of both virtual and real-life environments guaranteed that the processes of learning became more meaningful and successful for students. However, the blended course learners still required the guidance of the teacher. This means that using virtual learning environments does not replace the role of the teacher in the process of language learning; on the contrary, educators become the facilitators of those virtual experiences and help students during the exploration of them.

Internet technologies also enhanced the amount and quality of interaction with the texts. Learners did not have a passive relationship with information. Instead, they actively engaged the texts by using dictionaries, editing information, and even creating questions and new stories by using resources and tools for learning English. This process was enriched by creating connections between topics of texts and students' background knowledge, experiences, and perceptions of the world. 


\section{References}

Ariew, R., \& Ercetin, G. (2004). Exploring the Potential of Hypermedia Annotations for Second Language Reading. Computer Assisted Language Learning,17 (2), 237259. doi0.1080/0958822042000334253

Barton, D., Hamilton, M., \& Ivanič, R. (2000). Literacy Practices. In D. Barton, M. Hamilton \& R. Ivanič (Eds.), Situated Literacies: Reading and Writing in Context (pp. 7-15). London: Routledge.

Bear, R., Estreem, H., Fredricksen, J.E., \& Shepherd, D. (2014). Participation and Collaboration in Digital Spaces: Connecting High school and College Writing experiences. In R. McClure \&J.P.Purdy(Eds.), The Next Digital Scholar: A fresh Approach to the Common Core State Standards for Research and Writing(pp.131-174). Silver Spring, MA: ASIS\&T.

Cope, B., \& Kalantzis, M. (2000). The beginnings of an idea. In B. Cope \& $\mathrm{M}$. Kalantzis (Eds.), Multiliteracies: Literacy Learning and the Design of Social Futures, (pp. 3-8). London: Routledge.

Colombia. Ministerio de Educación Nacional [MEN] (2014). Colombia Very Well. Retrieved from/http:// www.colombiaaprende.edu.co/html/ micrositios/1752/articles-343287_ recurso_1.pdf

Colegio Trinidad Camacho Pinzón. (2016). Plan de asignatura Inglés-2016. Unpublished document.

Elliot, R., \& Timulak, L. (2005). Descriptive and interpretive approaches to qualitative research. In J. Miles \& P. Gilbert
(Eds.), Handbook of Research Methods for Clinical and Health Psychology (pp. 147160). Oxford, UK: Oxford University Press.

Garrison, R., \& Kanuka, H. (2004). Blended learning: Uncovering its transformative potential in higher education. Internet and Higher Education, 1, 95-105.

Greene, S., Cunningham, S., \& Moor, P. (2013). Cutting Edge Elementary: Third edition. UK: Pearson.

Jewitt, C. (2008). Multimodality and Literacy in School Classrooms. Review of

Research in Education, 32, 241-267. doi:10.3102/0091732X07310586

Johnson, R. B., \& Christensen, L. B. (2004). Educational research: Quantitative, qualitative, and mixed approaches. Boston, MA: Allyn and Bacon.

Hofmann, J., \& Miner, N. (2009).Tailored Learning: Designing the Blend That Fits. Alexandria, VA: ASTD.

Kress, G., \& Van Leeuwen, T. (1996). Reading images: The grammar of visual design. London: Routledge.

Lai, R. E. (2011). Collaboration. A literature Review. Retrieved from: http://images. pearsonassessments.com/images / tmrs/Collaboration-Review.pdf

Lankshear, C., \& Knobel, M. (2003). New literacies: Changing knowledge and classroom learning. Buckingham, UK: Open University Press.

Little Bird Tales. (2016). Retrieved from: https:/ / littlebirdtales.com/about/ default/

Maintz, J. (2009). Blending Spaces: Actornetwork Interactions of an Internet-based 
E-learning Course. Hamburg, Germany: LIT Verlag.

Prensky, M. (2001). Digital Natives, Digital Immigrants. Retrieved from: http://www. marcprensky.com/writing/Prensky \%20 -20Digital\%20Natives, $\% 20$ Digital $\% 20$ Immigrants\%20-\%20Part1.pdf

Rossett, A. (ed.) (2002). The ASTD E-Learning Handbook. New York: McGraw-Hill.

Rowsell, J., \& Walsh, M. (2011). Rethinking Literacy Education in New Times: Multimodality, Multiliteracies, \& New Literacies. Brock Education, 21 (1), 53-62. Rovai, A.P.,\& Jordan, H.M. (2004). Blended Learning and Sense of Community: A comparative analysis with traditional and fully online graduate courses. IRRODL, 5(2), 1-13.doi: 10.19173/irrodl. v5i2.192

Schrage, M. (1995). No more teams. New York, NY: Doubleday.
Snowdon, D., Churchill, E.F., \& Munro, A.J. (2000). Collaborative Virtual Environments: Digital spaces and places for interaction for CSCW: An Introduction. In D.Snowdon, E.F. Churchill \& A.J. Munro (Eds.), Collaborative Virtual Environments: Digital places and spaces for interaction(pp. 3-20). London, UK: Springer Verlag.

Tripp, D. (2005). Action research: a methodological introduction. Retrieved from: http://www.scielo.br/pdf/ep/ v31n3/en_a09v31n3.pdf

Unsworth, L. (2001). Teaching Multiliteracies across the Curriculum. Buckingham: Open University Press.

Vaarala, H., \& Jalkanen, J. (2010). Changing spaces, expanding mindsets: towards L2 literacies on a multimodal reading comprehension course. LanguageValue, 2 (1), 68-99. 


\section{Appendixes}

\section{Appendix 1: Questionnaire administered to students}

Querido estudiante, el siguiente cuestionario tiene como objetivo conocer sus percepciones sobre el trabajo realizado con la página "Little Bird Tales" y el uso de la tecnología en el aula de inglés. Responda de acuerdo a su opinión personal. Las respuestas dadas serán usadas de manera confidencial

\section{PERCEPCIONES DE LOS ESTUDIANTES}

1.1 Cuando afronta problemas en sus relaciones interpersonales con algún amigo, compañero o familiar ¿Cómo reacciona y qué hace frente a este problema?

1.2 ¿Cree usted que es posible establecer relaciones de amistad entre hombres y mujeres sin necesidad de llegar a romance?

1.3 Frecuentemente, cuando se le presentan problemas en su vida, ¿Cómo los soluciona? Evade la situación, hace actividades diferentes para escapar de la realidad o:

\section{USO DE LA TECNOLOGÍA}

2.1 ¿De qué manera aprendió a usar la página "Little Bird Tales”?

2.2 ¿Cuáles limitaciones encontró al usar la página web?

2.3 ¿Qué programas y herramientas aprendió a usar durante el desarrollo de las actividades en la página "Little Bird Tales"?

\section{APRENDIZAJE DEL INGLÉS}

3.1 ¿Cómo mejoró las siguientes habilidades en el aprendizaje del inglés?

- Lectura:

- Escritura: 
-Habla:

- Escucha

- Pronunciación:

3.2 ¿Qué ventajas y desventajas encontró al trabajar en grupo mientras que desarrollaba las actividades en la página web?

3.3 ¿Se sintió motivado al usar la página “Little Bird Tales" en la clase de inglés? Sí, No. ¿Por qué?

3.4 ¿Qué le gustó y qué no le gustó sobre trabajar con otros grupos de una institución diferente a esta? 